\title{
A társadalmi visszaillesztés problémái
}

\section{PISTYÚR Anett ${ }^{1}$}

\begin{abstract}
A tanulmány a társadalmi visszaillesztésre fektet hangsúlyt, amely több tényezőból áll: egyrészt a civil szféra, a szervezetek bevonásáról, az ő munkásságukról, másrészt a társadalom előitéletességéről, amely negatív tényezőként jelenik meg. A szabadulást követően nemcsak a volt fogvatartottakat kell felkészíteni a társadalmi életre, hanem annak családját, lakókörnyezetét is. A lakosság negatív attitüdjei részben a visszaillesztés eredménytelenségéhez vezetnek. A folyamatban a média szerepe is nagy: a nem objektív diskurzus félelmet és ellenszenvet kelthet hazánk polgárai körében. Ezt a folyamatot lehet semlegesíteni, de eredményességét csak hosszú távon lehet mérni. De vajon mit szólnak ehhez társadalmunk tagjai? Van-e erre befogadási kapacitásuk, és szeretnék-e a pozitív elöremozdulást?
\end{abstract}

Kulcsszavak: társadalmi visszaillesztés, fogvatartottak, civil szféra, előítélet, lehetséges problémák

A társadalmi visszaillesztés sikerességét számos nehézség akadályozza, amelyek leginkább külső környezeti tényezőkön alapulnak. Ezek nem lecsökkentik a visszaillesztés fontosságát, hanem egyfajta útmutatást nyújtanak a segítő szakembereknek szakterületük minden részén. A reintegráció teljességét különböző dilemmák befolyásolják, amelyek négy színtéren jelennek meg. Az első színtér a zárt intézetek világa, ahol - elvileg - megkezdődik a társadalmi reintegráció, a szabályokhoz való alkalmazkodás internalizálása, ami rendkívüli jelentőséggel bír. A második terület megjelenik mind a büntetés-végrehajtási intézetekben (továbbiakba: bv. intézet), illetve a szabadulás utáni szabad életben, ugyanis a civil szféra már a börtönök falain belül elkezdi támogató munkáját, és a szabadulás utáni fél-egy évben fontos szerephez jut a szabad világban. A harmadik terület maga a visszafogadó társadalom, amelynek előítélete a (volt) fogvatartott eddigi munkáját, hogy jobb útra térjen, nagymértékben visszavetheti. Az elöítéletet növeli a média nem teljesen széles körű tájékoztatása, valamint kis közösségekben nem elhanyagolandó a köznyelvi híresztelések szerepe, amelyek együttesen vezethetnek előítélethez, sztereotipizáláshoz lecsökkentve ezzel a szabadult fogvatartott esélyeit a normális beilleszkedéshez, a normakövető magatartás elsajátításához, valamint a munkaerőpiacon való szereplésben. Fontos továbbá a befogadó környezet, mind a szűk családi, mind pedig a kisebb lakókörnyezet hatása, hiszen felmerül a kérdés, hogy hogyan is lehetne sikeres a normakövető élet internalizálása, ha

PISTYÚR Anett Kitti, kriminológus, PhD-hallgató, ELTE ÁJDI, Kriminológia Program

Anett Kitti PISTYÚR, criminologist, PhD student at Eötvös Loránd University Faculty of Political Science and Law, Doctoral School, Criminlogy Program

orcid.org/0000-0001-5785-4750, pistyur.anett@gmail.com 
ugyanolyan környezetbe szabadulnak vissza ezek az emberek, amelyikből bekerültek a zárt intézetek világába, ha ugyanazok a prioritások szerepelnek az első helyen, mint a bebörtönzés előtt. A negyedik helyszín a társadalmi visszaillesztés problémakörében maga a fogvatartott, annak belső késztetései, motiváltsága, amelyet jelentősen befolyásol a lakókörnyezet és az első szocializációs színtér közötti diskurzus.

\section{Társadalmi visszaillesztés}

A társadalmi visszaillesztés egy komplex folyamat, amely magában foglalja a bv. intézetekben történő reintegrációt, illetve ezt kiegészítve a szabadulás utáni minden olyan segítő megmozdulást, amely a normakövető értékrend, a prevenció, valamint a bủnmegelőző folyamat a teljes körű internalizációt segíti elő. Ez a folyamat azért is összetett, mivel nagyon sok tényező szükséges a bűnkövető életmód elhagyásához.

\section{Zárt intézetek}

A visszaillesztés első fontos tényezője a rehabilitáció, ${ }^{2}$ amelynek során a bv. intézetekben arra kell törekedni, hogy a fogvatartottak testi, lelki és szellemi egészsége ne romoljon, hanem fejlődjön, javuljon. Ehhez a folyamathoz kapcsolódik szorosan a reintegráció, amelyet a büntetések, intézkedések, egyes kényszerintézkedések és a szabálysértési eljárásról szóló 2013. évi CCXL. törvény 164. §-a rögzít. ${ }^{3}$

A reintegráció ${ }^{4}$ magába foglalja az oktatást, a munkáltatást, a szabadidős vagy közművelődési tevékenységeket, a kapcsolattartást, illetve a szabályozás rendelkezik a jutalmazás és a fenyítés kérdésköréről is. A kapcsolattartás és annak ápolása az egyik leglényegesebb mozzanat a fogvatartottak és a kint lévő családjaik, rokonaik, barátaik számára, a visszaillesztés egyik alapköve a szabadítás után. Ezt kívánja erősíteni a törvény 165. §-a, amely a jutalmazás ${ }^{5}$ témakörét, annak engedélyezését taglalja, magában foglalva az előnyeit, amelyek a társas kapcsolatok erősítését célozzák meg.

Nagy jelentőséggel bír a reintegrációs őrizet bevezetése, valamint az utógondozás. A reintegrációs őrizet lényegi vonása, hogy a büntetés-végrehajtási bíró a bv. intézeti szabadságvesztés helyett a fogvatartott mozgási szabadságát írja elő (ennek szabályai 2017. január 1-jétől változtak, kibővültek).

Az utógondozásban a fogvatartott a saját kérelmére vehet részt, ennek leghosszabb ideje egy év. Ebben a szabadult a lakóhely szerint illetékes pártfogó felügyelővel, valamint a gondozásába bevont illetékes önkormányzattal, civil szervezetekkel működik együtt. A cél az, hogy a szabadult segítséggel tudjon munkahelyet, megfelelő lakóhelyet találni magának, és be tudjon illeszkedni az őt körülvevő társadalmi közegbe.

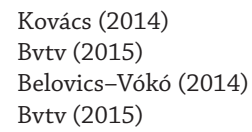


A bv. intézetekben a reintegrációs tisztek munkája mellett a Belügyminisztérium mint projektgazda támogatja a fogvatartottak visszailleszkedését különböző TÁMOP-os ${ }^{6}$ programok keretein belül. Így a TÁMOP 5.6.2. („Elítéltek többszakaszos, társadalmi és munkaerő-piaci reintegrációja és az intenzív utógondozási modelljének kialakítása") reintegrációs alprojekt megvalósítása 2010-ben kezdődött. A projekt célja a sikeres társadalmi visszailleszkedés, a munkaerőpiaci helyzet javítása és a bűnismétlés valószínűségének minimalizálása. A TÁMOP 5.6.3. alprogram („A fogvatartottak többszakaszos, társadalmi és munkaerőpiaci reintegrációja és az intenzív utógondozás modellje") célja ugyancsak a munkaerőpiaci helyzet javítása oktatás révén, illetve bünismétlés minimalizálása, azonban a programba bevonandó szereplőkkel kibővítve, azaz az előzetes letartóztatott fogvatartottakkal, a kényszergyógykezelés alatt álló fogvatartottakkal, a családtagokkal és a helyi közösséggel. A programban kiemelt szerepet kapott a resztoratív szemlélet az utógondozás során.

A társadalmi visszaillesztésnél nehézségként felmerülő problémák közé tartozik az a helyzet, amikor a fogvatartott nem a lakóhelyhez közeli bv. intézetben tölti a kiszabott szabadságvesztését (például ha vidéken tölti büntetését, de ipari városban él és az oktatás keretén belül állatgondozást tanult). Az alapfokú tanulmányok befejezése nem elég a munkaerőpiaci elhelyezkedéshez, vagy a fogvatartott nem is képzi magát sem alapfokú, sem másfajta képzésben. A munkáltatás szintjén felmerülő probléma, ha a fogvatartott nem a végzettségének megfelelő munkát végzi, sokszor monotóniát ${ }^{7}$ igénylő munkavégzésről van szó, illetve a bent végzett munkával a szabadulás után nem tud érvényesülni.

A személyi állomány részéről felmerülő probléma, hogy a reintegrációs tisztek leterheltsége miatt a prizonizációs ártalmak csökkentésében nem tudnak hatékonyan foglalkozni a fogvatartottakkal.

Az utógondozásnál problémát jelenthet, hogy csak saját kérelemre lehet igénybe venni, maximum egy éves időszakra, valamint a pártfogó felügyeletet végző szakemberek száma is alacsony ${ }^{8}$ (a bv. pártfogó-felügyelők száma 55 fő volt 2016 decemberéig). Az utógondozás azért is jelenik meg problémaként, mert nem kötelező a szabaduló fogvatartottak számára, mint feljebb is említettem, önkéntesen vehető igénybe, azaz a társadalomba visszailleszkedő személyek száma - akik segítséget vesznek igénybe - jelentősen lecsökken az összes szabaduló fogvatartott számához képest. Ez a csökkenés azt eredményezi, hogy a bünismétlési kockázat megnő azok számára, akik nem vették igénybe az utógondozás lehetőségét.

Az éppen szabaduló fogvatartottakoldalárólfelmerülő problémák szinténjelentősek, amelyek nagyban felerősítik a visszaesés esélyét. A fogvatartottak családi kapcsolatai gyakran tönkremennek, szabadulás után ugyanabba a rossz szociális közegbe kerülnek vissza, ahonnan bekerültek a bv. intézetekbe. Ha a családi kapcsolataik meg is maradnak, további gond lehet, hogy a család nincs megfelelően felkészítve a szabadulásra.

\footnotetext{
Bvop (2016)

Gál (2015)

Gál (2015)
} 
Alacsony iskolai végzettséggel ${ }^{9}$ a szabadultak igen nagy kihívás elé néznek álláskeresés közben. Gyakran olyan régióba szabadulnak, ahol, ha sikerül gyári munkában elhelyezkedniük (ahol azonban sokszor erkölcsi bizonyítványt kérnek), a két vagy három mûszakos rendben közel a minimálbért keresik meg, ami a megélhetéshez kevés.

\section{Civil szféra}

A civil szférába tartozik minden olyan alapítvány, egyház, szervezet és szerveződés, amely tevékenységével hozzájárul a szabadságvesztésüket töltő és letöltött személyek sikeres visszailleszkedéséhez. A civil szervezetek munkájukat már a bv. intézetekben megkezdik, ${ }^{10}$ amelynek elsődleges célja a börtönártalmak csökkentése, a vallás gyakorlása, különféle programok szervezése, jogi segítségnyújtás, illetve a monoton mindennapokból való kiszakadás.

\section{Vallásgyakorlás}

A vallásgyakorlás hozzájárulhat a börtönártalmak csökkentéséhez. Fontos szerepe van az önértékelés helyes kialakulásában, valamint az elkövetett cselekmények feldolgozásában. A vallás által kisközösségek jönnek létre, amelyek segítenek a valahová tartozás érzetének, illetve az egymás felé fordulás kialakulásában. Az egyházak szerepe a bv. intézetekben szélesebb körû́ is, hiszen egyfajta közvetítő szerepet tölt be, mind a fogvatartottak és fogva tartói kötött, mind pedig a fogvatartottak családja, valamint az áldozatok felé is. ${ }^{11}$

A börtönlelkészek mindennapjainak nagy részét az egyéni beszélgetések ${ }^{12}$ teszik ki, ugyanis hozzájuk a fogvatartottak ellenőrzés és korlátozás nélkül fordulhatnak. A zárt intézet keretein belül lévők könnyebben nyílnak meg, a rendszeres beszélgetéseken és egyéb vallási programokon részt vevők kommunikációja is más: itt nem az alá-fölé rendeltség a jellemző a diskurzusra, hanem egyenrangú félként vannak kezelve. A legtöbb fogvatartott számára ugyanakkor a vallásgyakorlás csupán egy eszköz arra, hogy a napok gyorsabban elteljenek. A börtönlelkészek a szabadulás előtt már iránymutatással segíthetnek, hogy a szabadulást követően hova, kihez, melyik szervezethez tudnak fordulni mind a leendő volt elítéltek, mind pedig azok családtagjai.

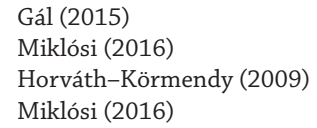




\section{Civil szervezetek}

A civil szférának a bv. intézetek falain belül és kívül is igen fontos szerepe van: olyan feladatokat vállal át az állam részéről, amelyek az igazgatásban felmerülő hiányosságokat pótolják ki. ${ }^{13}$

$\mathrm{Az}$ intézeteken belül végzett munkájukkal a civilek kiegészítik a reintegrációs tisztek munkáját, a kinti életre készítenek fel. Különböző programokkal, oktatásokkal segítik elő a társadalmi visszaillesztés komplexitását. Általában a legjellemzőbb segítési forma a jogi segítségnyújtás, de sok szervezet foglalkozik a munkavállalási és a lakhatási gondok megoldásával.

Ilyen komplex segítséget nyújt például a Tévelygőkért Alapítvány, amelynek a profilja kiterjed a jelenlegi fogvatartottakra és a szabadultakra. Az alapítvány szakmai hátterét a Feldmár Intézet adja. Az alapítvány profilja igen széles, megjelenik benne az utógondozásban való segítségnyújtás, a családi kötődés erősítése és nem utolsósorban a bűncselekmények megelőzése is. A szervezet három fő projektje:

- B-Terv: frissen szabadult, család nélküli, volt fogvatartottak részére készült ez a projekt, amelynek célja, hogy „akklimatizálódjanak” a kinti világhoz, az őket befogadó lakóközösségben. Ezt a programot 3-9 hónapig vehetik igénybe, az esetek többsége azt mutatja, hogy a szabadulás után ez az időszak a legkritikusabb, ilyenkor fordulhat elő nagyobb arányban a bűnismétlés. Ennek az az oka, hogy a társadalmi szabályok nem olyan merevek, rigidek, mint a börtönökben lévők, sokkal nagyobb a büncselekmények „csábítása”, mert a zárt intézeteken belül korlátozott a munka, a feladatok száma, míg idekint nem. Nagyobb a tér, nehezebb elhelyezkedni, amelynek esélyét csak rontja, ha az oktatásban való részvétel minimális volt.

- Mirko projekt: az alapítvány ezzel a programjával kifejezetten a fogvatartottak gyermekeivel foglalkozik, amelynek célja a szülö-gyermek kapcsolat erősítése, helyrehozása. Ezen cél érdekében múködik a szervezeten belül a Mesesarok, valamint a Mesekör. Ez utóbbi foglalkozáson megfigyelőként vettem részt 2015-ben a Balassagyarmati Fegyház és Börtönben. A Mesekör foglalkozás első részében kitaláltak egy kis történetet, és a további feladat az volt, hogy a résztvevőknek ki kellett találniuk a megadott történetnek három különböző befejezést. Fontos, hogy megtanulják, bevéssék a szabadulás előtt állók, hogy van választási lehetőségük a szabad világban is, csupán reálisan végig kell gondolni minden egyes mozzanat kimenetét. Ha ez sikerül, akkor fel tudják mérni, hogy a döntéseiknek mekkora súlya van.

Beszélj szabadon: ez a projekt érzékenyítő előadásokon alapszik középiskolások számára. A másfél órás előadás alatt tapasztalati munkatársak segítségével kommunikálnak a fiatalokkal, aminek a célja a szégyenmentes beszéd, az empátia és a tolerancia fejlesztése. Néhány szituációs feladatot is eljátszanak hasonlóan, mint a Mesekörben.

13 Bvop (2016) 
Hasonló feladatokat lát el a Váltósáv Alapítvány is, amelynek fókuszában a kriminális életvezetésű személyek állnak, mindhárom területen, azaz a prevencióban (szekunder, primer és tercier), a szabadulásban való felkészítésben és a szabadulás utáni integrácóban is nagy szerepet vállalnak. Két kiemelkedő projektben vállaltak szerepet, amelynek jelentősége minden bv. intézetben nagy lenne.

- KAB-ME-16-C-25639 - A szülői készségek fejlesztése speciális színtéren éscélcsoporttal.Aprogramfőcélkitűzéseiakövetkezőkvoltak:egészségfejlesztés, drogproblémákkal küzdő fogvatartottak szülői felelősségének kialakítása (apa és anya csoportokkal, ahol a szülők voltak bebörtönözve), valamint a szülői szerepek erősítése fiatalkorú bűnelkövetőknél.

- KAB-FF-16-B-25642 - Fókuszban egy speciális szükségletű csoport: fogvatartottak. Ennek célja az önismereti kompetenciák fejlesztése, a digitális kompetencia fejlesztése, illetve kortárssegítő képzés volt.

Magyarországon viszonylag sok civil szervezet múködik, munkásságukkal hozzájárulva a társadalmi visszaillesztés bonyolult folyamatához. A fent megismertetett alapítványok a teljesség igénye nélkül mutatják be, hogy a civil szervezetekre mekkora szükség van, hiszen az államtól vállalnak át olyan feladatokat, amelyeket többek között anyagi okok miatt már az nem tud felvállalni.

Vannak problémák, amelyek a társadalmi visszaillesztésnél nehézségként merülnek fel. A civil szféra oldaláról megközelítve igen széles körben behatároló a működésükhöz kapcsolódó anyagi bevétel, amely évről évre egyre kevesebb. A szervezetek eloszlása országos szinten nem egyenlő, nem egységes, a fővároshoz közeledve sokkal több civil szervezet múködik, mint például vidéken, valamint megítélésük a társadalom részéről elég változatos, noha a civil szféra múködése igencsak indokoltnak látszik - hiszen a szabadságvesztés büntetés ideje alatt is már a visszaillesztés kulcsszereplői - azonban jelenleg a bv. intézetekből való módszeres kitiltás a jellemző. Ez a tiltás remélhetőleg nem lesz sokáig érvényben, hiszen a társadalomnak sem mindegy, hogy a szabaduló fogvatartottak milyen lelkiállapotban, mekkora fokú mentális épséggel szabadulnak.

\section{Társadalmi előítélet}

Gordon Allport szerint az előítélet „valamely személlyel szemben érzett idegenkedő vagy ellenséges attitűd, aminek alapja pusztán annyiban van, hogy az illető személy egy adott csoporthoz tartozik, és ennek következtében feltételezik róla, hogy a csoportnak tulajdonított negatív tulajdonságokkal ô is rendelkezik". ${ }^{14}$ A sztereotípia egy olyan leegyszerúsítésen, túlzáson és torzításon alapuló negatív képzet, amely mindig egy adott csoportra, személyre irányul. ${ }^{15}$

\footnotetext{
Nagy (2003) 171.

5 Andorka (2006) 375.
} 
Mind az előítéletnek, mind pedig a sztereotípiának vannak elősegítő mechanizmusai, amelyeket a média és a kisközösség felerôsíthet.

A média sokszor torzít, nem mutat teljes képet. Széles körben elterjedtek a nem hiteles információkat adó internetes portálok, illetve a televízióban is sokszor tanúi lehetnek a fogyasztók, hogy nem pontosak az információk, amelyeket közvetítenek. Hazánkban a médiaszolgáltatásokról és tömegkommunikációról szóló 2010. évi CLXXXV. törvény szabályozza a búnügyi hírek maximális arányát. ${ }^{16}$ A Nemzeti Média- és Hírközlési Hatóság 2015-ben készült jelentése szerint az azonnali hatást kiváltó hírek sugárzásának a két nagyobb kereskedelmi csatorna szánt teret. A bűncselekmények aránya a hírmúsoraikban a műsoridő felét eléri vagy meg is haladja. Léteznek olyan médiakutatások, amelyek a deviancia és a bűnözés kapcsolatát vizsgálják, ahol egymással két, ellentétes megközelítés szerepel: az egyik szerint a média a bűnözést generálja/ fokozza. A másik álláspont szerint a médiatartalom nem a bűnözést növeli, hanem azokat az aggodalmakat, amelyek a jogrendünket veszélyezteti. A torz ábrázolás az irreális, nem valós félelmeket fokozza/generálja, amely által a társadalmi kontrollt növeli, így a demokratikus intézmények visszaszorulnak. Reiner rámutat, hogy a félelmekkel teli emberek sokkal könnyebben manipulálhatóak, ${ }^{17}$ fogékonyabbak a populizmusra, és ezen hatás által üdvözítőnek tartja a minél nagyobb elnyomást, a szigorú(bb) intézkedéseket. Gerbner szerint a televízió formálja, újraalkotja a valóságunkat bizonyos elemek kiemelésével, más elemek háttérbe szorításával.

2005-ben készült kutatás alapján, amelyet Pfeiffer és munkatársai végeztek, kimutatták, hogy Németországban 2003 előtti tíz évben a regisztrált bűncselekmények száma csökkent. A kutatásban megkérdezettek szerint azonban a bűncselekmények száma nőtt, és szerintük szigorúbb intézkedések vezethetnek a cselekmények számának csökkenéséhez. Az adott időszakban a televíziós hírközlésekben megnövekedett a bemutatott bűncselekmények száma, és ennek köszönhetően adták a fenti válaszokat a megkérdezettek.

Ez a negatív beállítottság a médiában pozitívabb szemléletű reklámokkal átfordítható lenne, de ehhez idő kell, hiszen a változáshoz legalább egy generáció kell, akik a gyermeknevelésben is alkalmazzák az elfogadást és elfogadják a másságot. (Másság alatt olyan meghatározás értendő, amelyben a többségi társadalomtól eltérő személyek és különbségek vannak, mint például a kisebbségek, a vallási különbségek, a különböző gazdasági helyzetű családok stb. Konkrét példa: a szülő a gyermeknevelés során az elfogadást részesítse előnyben függetlenül a saját helyzetétől). Érdemes lenne például a médiában jobban szerepeltetni a fogvatartottak munkáját is, amellyel a közjót szolgálják, hiszen ezekről nagyon keveset lehet hallani mind a televízióban, mind a sajtóban.

A kutatások szerint a média közvetítő szereppel rendelkezik, és annyiban változtatja meg a személyek attitűdjeit, viselkedéseit, amennyiben a fogyasztók valósnak, igaznak érzik annak tartalmát. ${ }^{18}$ Befolyásoló hatása főként a fiatalok körében nyilvánul

\footnotetext{
Virág (2016) 401-412.

Virág (2016) 413-414.

18 Kósa (2015)
} 
meg. Egy általam készített mini kutatás is igazolta, hogy az internetes médiafogyasztók nagy többsége olyan tartalmakból szerzi információikat, amelyek hiteles, tényfeltáró forrásokból származnak.

Kis közösségekben ugyanilyen romboló hatást lehet elérni a pletykával, amellyel valakinek a rossz hírét kelthetik úgy is, hogy torzított információt adnak tovább az emberek egymásnak, illetve úgy is, hogy nem adják meg az esélyt sem a védekezésre a pletyka tárgyát képező személynek.

Elias Winston parvai ${ }^{19}$ kutatása példát hozott az egyének társadalmi helyzetében lévő státuszviszonyok közötti rivalizálásra. Eszerint az egyének azzal érnek el magasabb státuszokat egy adott csoporton belül (például vidéken, egy adott településen belül), ha találnak a saját nézeteikkel lojális közönséget, amelynek egy, a csoportba nem tartozó félről tud deformáló információkat átadni. Winston szerint, ha a csoport tagjai meg vannak győződve felsőbbrendűségükről, de nem észlelnek veszélyt a külső csoportból, akkor a deformitás mértéke kisebb, azonban ha társadalmi helyzetüket tekintve veszélyeztetve érzik magukat, annál nagyobb valószínűséggel sokkal nagyobb torzítással fognak információkat cserélni.

\section{Konklúzió}

A tanulmányban említett problémák sokrétűsége ellenére számos pozitív példa van, hogy a társadalmi visszaillesztés folyamata müködik. A felmerülő problémákra egyenként vizsgálva kell megoldásokat találni, amely egy külön kutatás témája lehet. Egy elkészült minikutatásom alapján megfigyelhető, hogy a szociális érzékenyítésre szükség van, a társadalom szabad tagjai hajlanak a szabadult személyek segítésére, amelyet azonban nagymértékben befolyásol az elkövető cselekménye. Számos lehetőség rejtőzik a civil szférában, a médiában, amelyek segítségével ezek a sztereotípiák, előítéletek csökkenthetőek, ami nyilvánvalóan hosszú távon fejtené ki pozitív hatását. A sikeres társadalomba való visszailleszkedés záloga azonban végső soron nem más, mint maga a szabaduló, ugyanis önakaratán kívül senkin nem lehet segíteni.

\section{IRODALOMJEGYZÉK}

Andorka Rudolf (2006): Bevezetés a szociológiába. Budapest, Osiris Kiadó.

Belovics Ervin - Vókó György (2014): A büntetés-végrehajtási törvény magyarázata. Budapest, HVGORAC.

A büntetés-végrehajtási pártfogó felügyelői tevékenység. Forrás: https://bv.gov.hu/hu/a-buntetesvegrehajtasi-partfogo-felugyelet (2017. 11. 06.)

Gál Levente (2015): A munkaerő-piacon innen, a börtönön túl. A büntetés-végrehajtási intézetből szabadult rabok esélyei a legális munkaerő-piacon. In Életkeretek a börtönön innen és túl, Szubjektív reszocializációs esélyek. Budapest, MTA Társadalomtudományi Kutatóközpont. 24-57.

19 Szvetelszky (2011) 
Horváth Márta - Körmendy András (2009): A fogvatartottak vallásgyakorlása - jogi szabályozás és jogalkalmazás hazánkban és külföldön. Börtönügyi Szemle, 28. évf. 3. sz. 21-48.

Kovács Krisztina (2014): Fiatalkorú bűnelkövetők reszocializációs nevelése: Speciálpreventív beavatkozások a szabadságvesztés alatt és azt követően In Izsák-Somogyi Katalin szerk.: A jogászság kezdete: A XXXI. OTDK állam- és jogtudományi szekciójában I. helyezést elért hallgatók ünnepi kötete. Budapest, Complex Wolters-Kluwer.

Kósa Éva (2015): A médiaszocializáció kezdetei. In Kósa Éva szerk.: Médiaszocializáció. Budapest, Wolters-Kluwer. 20-25.

Miklósi Márta (2016): Társadalmi szervezetek és egyházak az elítéltek reintegrációjában. Zempléni Múzsa, 16. évf. 2. sz. 29-39.

Miklósi Márta (2016): A büntetés-végrehajtási szervezet reintegrációs tevékenységeinek új rendszere. Iskolakultúra, 26. évf. 5. sz. 48-62.

Nagy László (2003): Szociálpszichológia. Pécs, Comenius Bt.

Szvetelszky Zsuzsanna (2010): A pletyka pszichológiája. Doktori értekezés. Pszichológia doktori iskola szociálpszichológia program. Forrás: http://pea.lib.pte.hu/bitstream/handle/pea/15274/szvetelszky-zsuzsanna-tezis-hun-2011.pdf? sequence=2\&isAllowed $=y$ (2018. 03. 10.)

TÁMOP 5.6.2-10/1-2010-0001 A társadalmi kohéziót erősítő bủnmegelőzési és reintegrációs programok módszertani megalapozása.

TÁMOP 5.6.3-12/1-2012-0001 A fogvatartottak többszakaszos, társadalmi és munkaerőpiaci reintegrációja és az intenzív utógondozás modellje.

\section{Jogforrás}

A büntetések, az intézkedések és a szabálysértési elzárás végrehajtásáról szóló 2013. évi CCXL. törvény

\section{Internetes források}

B-Terv. Forrás: www.tevelygokertalapitvany.info/about1-c1jsq (2017. 06. 04.)

Beszélj szabadon! Forrás: www.tevelygokertalapitvany.info/properties (2017. 06. 04.)

Reintegrációs őrizet szabályainak módosítása. Forrás: https://lorik.hu/reintegracios-orizet-szabalyainak-modositasa/ (2018. 03. 05.)

Tévelygőkért Alapítvány. Forrás: www.tevelygokertalapitvany.info/rolunk (2017. 08. 09.)

Váltó-sáv Alapítvány. Forrás: www.valtosav.hu/magunkrol.html (2018. 03. 10.)

\section{ABSTRACT}

\section{Problems of Social Reintegration}

PISTYÚR Anett

The study focuses on social reintegration, which consists of several factors: the involvement of the civil sphere and organizations, their own work; it also focuses on the prejudices of society, which is apparently a negative factor. After their release, not only the former detainees have to be prepared for social life, but their family and living environment, as well. The negative attitudes of the population partly lead to the ineffectiveness of reintegration. The role of media is great in this process: non-objective discourse can create fear and dislike among our citizens. This process can 
PISTYÚR Anett: A társadalmi visszaillesztés problémái

be neutralized, yet its efficiency can only be measured in the long run. But what do the members of our society say about this? Do they have the recipience and would they be keen on a positive furtherance?

Keywords: social reintegration, detainees, NGO, stereotype, occurrent problems 